\title{
Biomineralization of calcium carbonates and their engineered applications: a review
}

\author{
Navdeep K. Dhami ${ }^{1}$, M. Sudhakara Reddy ${ }^{1 *}$ and Abhijit Mukherjee ${ }^{2}$ \\ ' Department of Biotechnology, Thapar University, Patiala, India \\ ${ }^{2}$ Department of Civil Engineering, Indian Institute of Technology, Gandhinagar, India
}

\section{Edited by: \\ Naoto A. Yoshida, University of \\ Miyazaki, Japan}

Reviewed by:

Naoto A. Yoshida, University of

Miyazaki, Japan

Kirsten Küsel,

Friedrich-Schiller-University Jena,

Germany

\section{*Correspondence:}

M. Sudhakara Reddy, Department of

Biotechnology, Thapar University,

Bhason Road, Patiala 147004,

Punjab, India

e-mail:msreddy@thapar.edu
Microbially induced calcium carbonate precipitation (MICCP) is a naturally occurring biological process in which microbes produce inorganic materials as part of their basic metabolic activities. This technology has been widely explored and promising with potential in various technical applications. In the present review, the detailed mechanism of production of calcium carbonate biominerals by ureolytic bacteria has been discussed along with role of bacteria and the sectors where these biominerals are being used. The applications of bacterially produced carbonate biominerals for improving the durability of buildings, remediation of environment (water and soil), sequestration of atmospheric $\mathrm{CO}_{2}$ filler material in rubbers and plastics etc. are discussed. The study also sheds light on benefits of bacterial biominerals over traditional agents and also the issues that lie in the path of successful commercialization of the technology of microbially induced calcium carbonate precipitation from lab to field scale.

Keywords: biomineralization, bacteria, urease, biofilm, extrapolymeric substances, calcite

\section{INTRODUCTION}

"Biominerals are everywhere." If we take a look around, we see ourselves surrounded by biominerals whether in the form of beautiful corals, ant hills, caves, shells of mollusks, teeth, bones or rocks (Figure 1). Researchers around the globe are now focusing on harnessing the technical applications of these biominerals in various fields.

Biomineralization is a process by which living organisms produce minerals. These could be silicates in algae and diatoms, carbonates in invertebrates and calcium, phosphates and carbonates in vertebrates. The synthesis of minerals by prokaryotes is broadly classified into two classes: Biologically controlled mineralization (BCM) and Biologically induced mineralization (BIM) (Lowenstam, 1981; Lowenstam and Weiner, 1989). Minerals are directly synthesized at a specific location within or on the cell and only under certain conditions in case of BCM but in case of biologically induced mineralization, the minerals are formed extracellularly as a result of metabolic activity of the organism. The extracellular production of these biominerals invited scientists worldwide for harnessing this capability of microbes for various bioengineering applications.

Minerals known to be formed via biologically induced mineralization through passive surface-mediated mineralization include $\mathrm{Fe}, \mathrm{Mn}$, and other metal oxides, e.g., ferrihydrite $\left(5 \mathrm{Fe}_{2} \mathrm{O}_{3} \cdot 9 \mathrm{H}_{2} \mathrm{O}\right)$, hematite $\left(\alpha-\mathrm{Fe}_{2} \mathrm{O}_{3}\right)$, and goethite $(\alpha-\mathrm{FeOOH})$; metal sulfates, phosphates, and carbonates; phosphorite; $\mathrm{Fe}$ and Fe-Al silicates; and metal sulfides. Of all the minerals that have been associated with biomineralization, carbonates are the most obvious. Microbially induced calcium carbonate precipitation (MICCP), most widely studied branch of biomineralization holds promise for variety of fields ranging from Biotechnology, Geotechnology, Paleobiology to Civil
Engineering. It has implications for: (1) atmospheric $\mathrm{CO}_{2}$ fixation through carbonate sediment formation and lithification (Krumbein, 1979; Monger et al., 1991; Chafetz and Buczynski, 1992; Folk, 1993) and dolomite precipitation (Vasconcelos et al., 1995 ) (2) solid-phase capture of inorganic contaminants (Warren et al., 2001) (3) pathological formation of mineral concretions, such as gallstones and kidney stones in humans (Keefe, 1976) (4) the possibility of understanding extraterrestrial biological processes such as Martian carbonate production by bacteria (McKay et al., 1996; Thomas-Keprta et al., 1998).

\section{MICROBIALlY INDUCED $\mathrm{CaCO}_{3}$ PRECIPITATION}

Calcium carbonate precipitation is a rather straightforward chemical process governed mainly by four key factors: (1) the calcium concentration, (2) the concentration of dissolved inorganic carbon (DIC), (3) the $\mathrm{pH}$ and (4) the availability of nucleation sites (Hammes and Verstraete, 2002). $\mathrm{CaCO}_{3}$ precipitation requires sufficient calcium and carbonate ions so that the ion activity product (IAP) exceeds the solubility constant $\left(K_{\mathrm{so}}\right)$ [Equations (1) and (2)]. From the comparison of the IAP with the $K_{\text {so }}$, the saturation state $(\Omega)$ of the system can be defined: if $\Omega>1$ the system is oversaturated and precipitation is likely (Morse, 1983) as:

$$
\begin{aligned}
& \mathrm{Ca}^{2+}+\mathrm{CO}_{3}^{2-} \longleftrightarrow \mathrm{CaCO}_{3} \\
& \Omega=a\left(\mathrm{Ca}^{2+}\right) a\left(\mathrm{CO}_{3}^{2-}\right) / K_{\text {so }} \text { with } K_{\text {so calcite, } 25^{\circ}}=4.8 \times 10^{-9}(2)
\end{aligned}
$$

The concentration of carbonate ions is related to the concentration of DIC and the $\mathrm{pH}$ of a given aquatic system. In addition, the concentration of DIC depends on several environmental parameters such as temperature and the partial pressure of carbon 


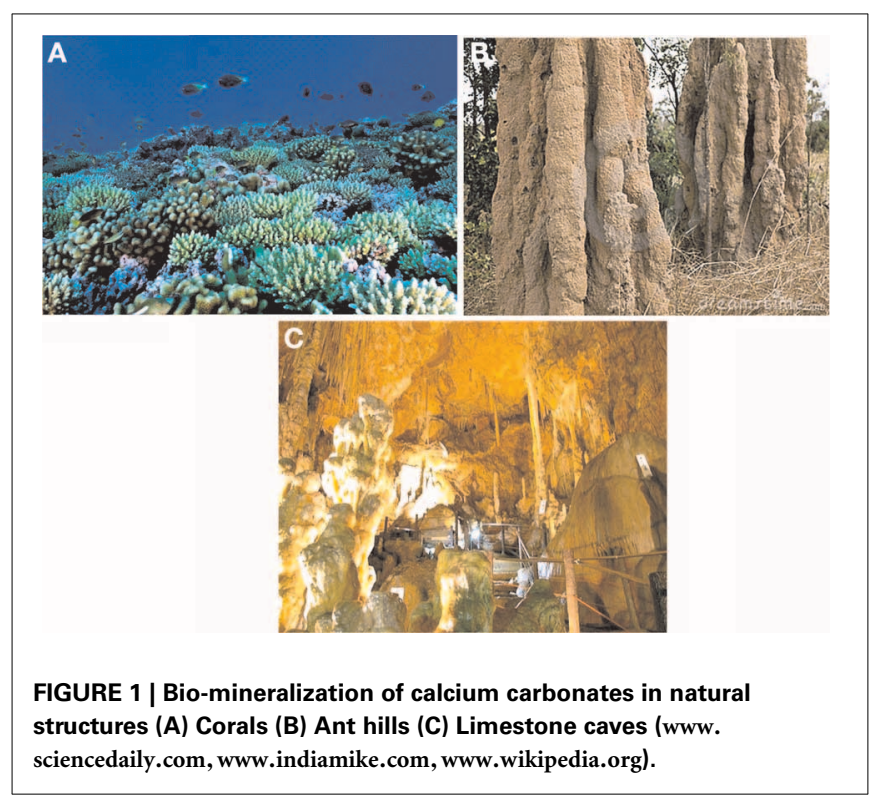

dioxide (for systems exposed to the atmosphere). The equilibrium reactions and constants governing the dissolution of $\mathrm{CO}_{2}$ in aqueous media $\left(25^{\circ} \mathrm{C}\right.$ and $\left.1 \mathrm{~atm}\right)$ are given in Equations (3)-(6) (Stumm and Morgan, 1981):

$$
\begin{array}{r}
\mathrm{CO}_{2(g)} \longleftrightarrow \mathrm{CO}_{2(\text { aq. })}\left(p K_{H}=1.468\right) \\
\mathrm{CO}_{2 \text { (aq.) })}+\mathrm{H}_{2} \mathrm{O} \longleftrightarrow \mathrm{H}_{2} \mathrm{CO}_{3} *(p K=2.84) \\
\mathrm{H}_{2} \mathrm{CO}_{3} * \longleftrightarrow \mathrm{H}^{+}+\mathrm{HCO}_{3}^{-}(p K 1=6.352) \\
\mathrm{HCO}_{3}^{-} \longleftrightarrow \mathrm{CO}_{3}^{2-}+\mathrm{H}^{+}(p K 2=10.329)
\end{array}
$$

With $\mathrm{H}_{2} \mathrm{CO}_{3} *=\mathrm{CO}_{2 \text { (aq.) }}+\mathrm{H}_{2} \mathrm{CO}_{3}$.

Under natural conditions, the precipitation of carbonates occurs very slowly over long geological times but in order to produce large amounts of carbonates shortly there is need to look for microbes with the ability to create conditions for precipitation of carbonates in shorter times. Different bacterial species precipitate carbonates in alkaline environments rich in $\mathrm{Ca}^{2+}$ ions and various mechanisms which could induce precipitation by bacteria in natural habitats have been proposed (Ehrlich, 1996; Rivadeneyra et al., 2004). Though, the precise role of bacteria and bacterial activities in carbonate crystallization remains unclear, they seem to fall in 3 categories:

- As per the first hypothesis, mineralization occurs as a byproduct of microbial metabolism (Rivadeneyra et al., 1994; Douglas and Beveridge, 1998; Castanier et al., 1999; Lian et al., 2006);

- As per the second hypothesis, carbonate nucleation takes place on the cell wall (Rivadeneyra et al., 1998; Castanier et al., 2000) and

- Lastly, the third hypothesis involves role of extracellular macromolecules (Ercole et al., 2007; Decho, 2009).

Mainly four groups of microorganisms are seen to be involved in the process (i) Photosynthetic organisms - such as cyanobacteria and algae

(ii) Sulphate reducing bacteria-that are responsible for dissimilatory reduction of sulphates

(iii) Organisms utilizing organic acids

(iv) Organisms that are involved in the nitrogen cycle either ammonification of amino acids/ nitrate reduction/ hydrolysis of urea (Stocks-Fischer et al., 1999; Hammes and Verstraete, 2002).

Of all the above, Microbially induced calcium carbonate precipitation (MICCP) via urea hydrolysis is the simplest and most widely used method for precipitation of carbonates for several technical applications.

\section{MICCP VIA UREA HYDROLYSIS}

The precipitation of carbonates via urea hydrolysis by ureolytic bacteria is the most straightforward and most easily controlled mechanism of MICCP with potential to produce high amounts of carbonates in short period of time. During microbial urease activity, $1 \mathrm{~mol}$ of urea is hydrolyzed intracellularly to $1 \mathrm{~mol}$ of ammonia and $1 \mathrm{~mol}$ of carbonate (Equation 7), which spontaneously hydrolyzes to form additional $1 \mathrm{~mol}$ of ammonia and carbonic acid (Equation 8) as follows:

$$
\begin{array}{r}
\mathrm{CO}\left(\mathrm{NH}_{2}\right)_{2}+\mathrm{H}_{2} \mathrm{O} \stackrel{\text { bacteria }}{\longrightarrow} \mathrm{NH}_{2} \mathrm{COOH}+\mathrm{NH}_{3} \\
\mathrm{NH}_{2} \mathrm{COOH}+\mathrm{H}_{2} \mathrm{O} \longrightarrow \mathrm{NH}_{3}+\mathrm{H}_{2} \mathrm{CO}_{3}
\end{array}
$$

These products equilibrate in water to form bicarbonate, 1 mol of ammonium and hydroxide ions which give rise to $\mathrm{pH}$ increase

$$
\begin{array}{r}
\mathrm{H}_{2} \mathrm{CO}_{3} \longrightarrow 2 \mathrm{H}^{+}+2 \mathrm{CO}_{3}^{2-} \\
\mathrm{NH}_{3}+\mathrm{H}_{2} \mathrm{O} \longrightarrow \mathrm{NH}^{4+}+\mathrm{OH}^{-} \\
\mathrm{Ca}^{2+}+\mathrm{CO}_{3}^{2-} \longrightarrow \mathrm{CaCO}_{3}\left(K_{S P}=3.8 \times 10^{-9}\right)
\end{array}
$$

$K_{S P}$ is the solubility product in Equation 11.

The primary role of bacteria has been ascribed to their ability to create an alkaline environment through various physiological activities (Figure 2). Bacterial surfaces also play an important role in calcium precipitation (Fortin et al., 1997). Due to the presence of several negatively charged groups, at a neutral $\mathrm{pH}$, positively charged metal ions could be bound on bacterial surfaces, favoring heterogenous nucleation (Douglas and Beveridge, 1998; Bäuerlein, 2003). Commonly, carbonate precipitates develop on the external surface of bacterial cells by successive stratification (Pentecost and Bauld, 1988; Castanier et al., 1999) and bacteria can be embedded in growing carbonate crystals (Rivadeneyra et al., 1998; Castanier et al., 1999).

Possible biochemical reactions in urea- $\mathrm{CaCl}_{2}$ medium to precipitate $\mathrm{CaCO}_{3}$ at the cell surface can be summarized as follows:

$$
\begin{array}{r}
\mathrm{Ca}^{2+}+\text { Cell } \longrightarrow \text { Cell }-\mathrm{Ca}^{2+} \\
\mathrm{Cl}^{-}+\mathrm{HCO}^{3-}+\mathrm{NH}_{3} \longrightarrow \mathrm{NH}_{4} \mathrm{Cl}+\mathrm{CO}_{3}^{2-} \\
\text { Cell }-\mathrm{Ca}^{2+}+\mathrm{CO}_{3}^{2-} \longrightarrow \text { Cell }-\mathrm{CaCO}_{3}
\end{array}
$$




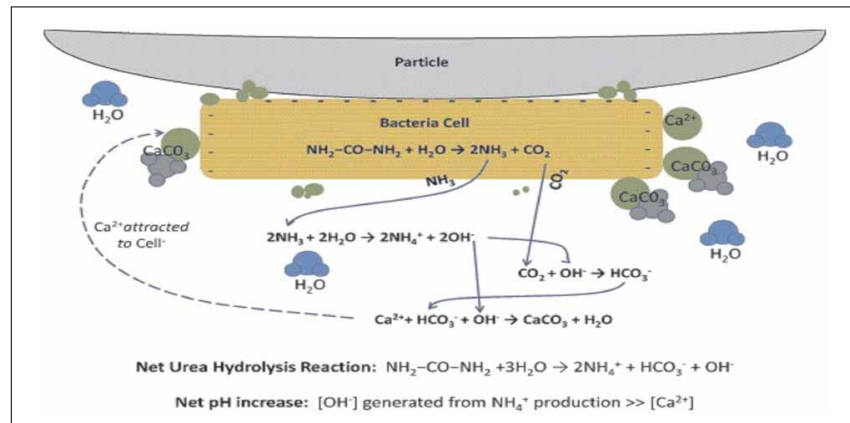

FIGURE 2 | Bacteria serving as nucleation site for $\mathrm{CaCO}_{3}$ precipitation in the sand particles (Source: DeJong et al., 2010).

\section{ENZYME UREASE}

Several authors have investigated various conditions for calcium carbonate precipitation via urea hydrolysis (Table 1). The actual role of the bacteria in the precipitation remains, however, a matter of debate. Some authors believe this precipitation to be an unwanted and accidental by-product of the metabolism (Knorre and Krumbein, 2000) while others think that it is a specific process with ecological benefits for the precipitating organisms (Ehrlich, 1996; Mc Connaughey and Whelan, 1997). These bacteria include Bacillus pasteurii, Pseudomonas sp., Variovorax sp., Leuconostoc mesenteroides, Micrococcus sp., Bacillus subtilis, Deleya halophila, Halomonas eurihalina and Myxococcus xanthus (Mobley and Hausinger, 1989; Rivadeneyra et al., 1991, 1996, 1998; Ferris and Stehmeier, 1992; Stocks-Fischer et al., 1999; Tiano et al., 1999; Castanier et al., 2000; Fujita et al., 2000; Rodriguez-Navarro et al., 2003).

\section{POLYMORPHISM OF CARBONATE CRYSTALS}

Studies have reported that bacterial induced calcium carbonate precipitation results in the production of different phases of $\mathrm{CaCO}_{3}$ (Rodriguez-Navarro et al., 2012; Rusznyak et al., 2012; Dhami et al., 2013a). Calcium carbonate forms three anhydrous polymorphs: calcite, aragonite and vaterite, two hydrated crystalline phases: monohydrocalcite $\left(\mathrm{CaCO}_{3} \cdot \mathrm{H}_{2} \mathrm{O}\right)$ and ikaite $\left(\mathrm{CaCO}_{3} \cdot 6 \mathrm{H}_{2} \mathrm{O}\right)$, and various amorphous phases (ACC) with differences in short range order and degree of hydration (Somasundaran and Agar, 1967; Lippmann, 1973; Rieger et al., 2007; Gower, 2008; Gebauer et al., 2010) (Figure 3). Although vaterite and calcite are the most common bacterial calcium carbonate polymorphs (Ben Chekroun et al., 2004; RodriguezNavarro et al., 2007; González-Muñoz et al., 2011), mineralization of monohydrocalcite (Krumbein, 1979) and aragonite (Krumbein, 1974; Sánchez-Navas et al., 2009) have also been reported. The evidence that bacterial mineralization of calcium carbonate involves the formation of ACC precursor phases is also growing (Hammes et al., 2003; Benzerara et al., 2006; Chen et al., 2009). The species specific precipitation of carbonate biominerals by various bacterial isolates has also been reported by many (Hammes et al., 2003; Rusznyak et al., 2012; Dhami et al., 2013a). But despite extensive studies on bacterial carbonatogenesis, little is known on what is the cause(s) of polymorph selection during bacterial calcium carbonate mineralization. Studies suggested
Table 1 | Reaction conditions reported in the literature for production of $\mathrm{CaCO}_{3}$ via urea hydrolysis.

\begin{tabular}{|c|c|c|c|c|}
\hline Purpose & $\begin{array}{l}\text { Urea } \\
(\mathrm{mM})\end{array}$ & $\begin{array}{l}\mathrm{Ca}^{2+} \\
(\mathrm{mM})\end{array}$ & $\begin{array}{l}\text { Urease activity } \\
(\mathrm{mM} / \mathrm{min})\end{array}$ & Reference \\
\hline $\mathrm{Sr}^{90}$ sequestration & 333 & 25 & 0.045 & Fujita et al., 2000 \\
\hline $\mathrm{Sr}^{90}$ sequestration & 330 & 0.025 & 0.042 & Warren et al., 2001 \\
\hline $\begin{array}{l}\text { Removal of } \mathrm{Ca}^{2+} \\
\text { from waste water }\end{array}$ & 16 & 14 & 0.293 & Hammes et al., 2003 \\
\hline $\begin{array}{l}\text { Removal of } \mathrm{Ca}^{2+} \\
\text { from waste water }\end{array}$ & 8 & 15 & 0.032 & Hammes, 2002 \\
\hline \multirow[t]{2}{*}{ Stone remediation } & 333 & $12-50$ & 0.110 & $\begin{array}{l}\text { Stocks-Fischer et al., } \\
1999\end{array}$ \\
\hline & 333 & 340 & $0.02-0.12$ & $\begin{array}{l}\text { De Muynck et al., } \\
2011\end{array}$ \\
\hline Stone remediation & 66 & 25 & 0.041 & $\begin{array}{l}\text { Bachmeier et al., } \\
2002\end{array}$ \\
\hline $\begin{array}{l}\text { Portland cement } \\
\text { remediation }\end{array}$ & 333 & 50 & $n / s$ & Ramachandran, 2001 \\
\hline $\begin{array}{l}\text { Plugging of rock } \\
\text { pores }\end{array}$ & 333 & 0.25 & $n / s$ & Gollapudi et al., 1995 \\
\hline Biocementation & 1500 & 1500 & $4-18$ & Whiffin, 2004 \\
\hline $\begin{array}{l}\text { Sand column } \\
\text { cementation }\end{array}$ & 333 & 25 & 0.65 & $\begin{array}{l}\text { Achal et al., 2009a; } \\
\text { Van Paassen, } 2009\end{array}$ \\
\hline Soil cementation & 1000 & 1000 & $n / s$ & Cheng et al., 2013 \\
\hline Biodeposition & 333 & 340 & $n / s$ & $\begin{array}{l}\text { De Belie and De } \\
\text { Muynck, } 2008\end{array}$ \\
\hline $\begin{array}{l}\text { Carbonate } \\
\text { precipitation }\end{array}$ & 666 & 250 & $n / s$ & $\begin{array}{l}\text { Okwadha and Li, } \\
2010\end{array}$ \\
\hline
\end{tabular}

that phase, amount and morphology of calcium carbonate minerals depend on supersaturation, temperature, $\mathrm{pH}$ and $\left[\mathrm{Ca}^{2+}\right]$ / $\left[\mathrm{CO}_{32}^{-}\right]$ratio. The saturation index, $S I=\log \Omega=\log \mathrm{IAP} / K_{s}$; where $\Omega$ is the saturation state of the system, IAP is the ion activity product and $\mathrm{K}_{s}$ is the thermodynamic solubility product of the relevant phase. Calcium carbonate precipitation in microbial systems typically occurs when the saturation index (with respect to calcite) is above 1 (Arp et al., 2001; Mitchell and Ferris, 2006). Along with this, organics also play important role in the carbonate precipitation. The organics act as crystallization inhibitors (when in solution) and prevent the nucleation of calcium carbonate even at high SI values (Rodriguez-Navarro et al., 2007). It follows that bacterial presence and activity are a prerequisite for the precipitation of calcium carbonate. The bacterial metabolic activity produces the necessary increase in supersaturation as to induce the heterogeneous crystallization of calcium carbonate.

Besides its scientific interest, calcium carbonate polymorph selection can have important technical implications (Meldrum and Cölfen, 2008). For instance, the bacterial conservation of building materials requires the formation of a coherent, durable, calcium carbonate cement i.e., calcite. This is not fully achieved if metastable vaterite (more soluble than calcite) is formed during a bacterial conservation treatment (Rodriguez-Navarro et al., 2003). 


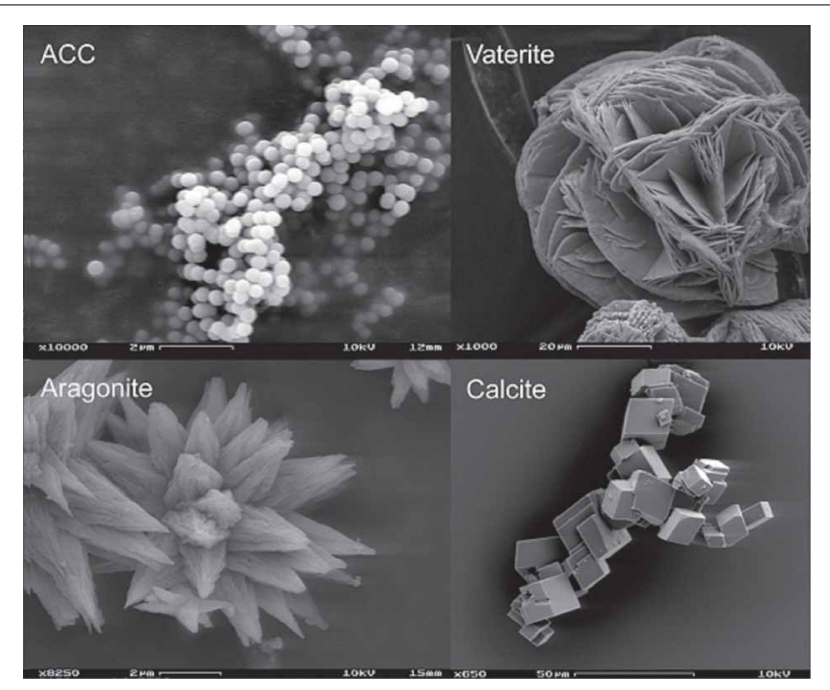

FIGURE 3 | Polymorphs of $\mathrm{CaCO}_{3}$ (http://www.ruhr-uni-bochum.de/ sediment/forschung.html).

\section{APPLICATIONS OF BIOMINERALS}

The use of bacterially induced carbonate biominerals is becoming increasingly popular day by day. From removal of heavy metals and radionucleotides, removal of calcium from wastewater and biodegradation of pollutants, atmospheric $\mathrm{CO}_{2}$ sequestration, remediation of building materials, modifying the properties of soil and filler in rubber and plastics to fluorescent markers in stationery ink, bacterial carbonates are serving many fields.

\section{REMOVAL OF HEAVY METALS AND RADIONUCLIDE}

Heavy metals and radionuclides pose greatest challenges for their disposal. They are threatening not only to human health but to the entire environment. Remediation of ground water from radionuclides has been the topic of immediate attention and several measures have being taken for it (Warren et al., 2001; Fujita et al., 2004, 2008, 2010; Wu et al., 2011). Traditional methods of using pump and treat have been found ineffective (Fujita et al., 2008) and paved way for applications of ureolytic bacteria capable of $\mathrm{CaCO}_{3}$ precipitation. In this, biomineralization of radionuclide and contaminant metals into calcite occurs as competitive co-precipitation reaction in which suitable divalent cations are incorporated into the calcite lattice.

$$
{ }^{90} \mathrm{Sr}^{2+}+\mathrm{OH}^{-}+\mathrm{HCO}_{3}^{-}=\mathrm{SrCO}_{3}(\mathrm{~s})+\mathrm{H}_{2} \mathrm{O}
$$

These cations and radionuclides integrate into the calcite structure via substitution of calcium ions in the microenvironment of the mineral precipitate, forming low - strontium carbonate minerals which have very low solubility (Fujita et al., 2000, 2004; Smith et al., 2004; Colwell et al., 2005; Mitchell and Ferris, 2006). Warren et al. (2001) reported $95 \%$ capturing of the total strontium in solid phase by Microbially induced calcite precipitation (MICP) with application of $S$. pasteurii. Fujita et al. (2008) successfully investigated the potential of enriching native ureolytic organism in situ for remediation of ground water by co-precipitation of Strontium.

Metal contamination of soil is especially problematic because of strong adsorption of many metals to the surfaces of soil particles. For removal of toxic metals, the conventional methodologies include phytoremediation, on site chemical leaching of contaminants, bioremediation by toxic metal tolerant bacterial species (Achal et al., 2012) but all these treatments are expensive and not successful for long terms. Other treatments include addition of cement or chemical fixatives, by capping with asphalt, or by in situ vitrification and excavation and confinement of soils in hazardous waste facilities (Schleck, 1990). Although rapid in effect, both of these options are expensive $\left(\$ 30-300 / \mathrm{m}^{3}\right)$ and destroy the soil's future productivity (Cunningham et al., 1995).

MICCP has come up as a novel solution to this problem. Recently Achal et al. (2012) reported the positive potential of Sporosarcina ginsengisoli CR 5 for remediation of Arsenic contaminated sites as well as copper bioremediation by Kocuria flava CR1 (Achal et al., 2011b). Kurmaç (2009) also investigated the impact of varying concentrations of different metals as lead, cadmium, chromium, zinc, copper and nickel in MICP technology and reported that metal toxicity do play important role in microbial substrate degradation.

\section{REMOVAL OF CALCIUM IONS AND POLYCHLORINATED BIPHENYLS (PCBs)}

The presence of a high concentration of calcium ions (500$1500 \mathrm{mgL}^{-1}$ ) in the wastewater causes severe scaling in the pipelines and reactors due to calcium formation as carbonate, phosphate and/or gypsum. Hammes et al. (2003) studied the potential of removing $\mathrm{Ca}^{2+}$ ions from industrial wastewaters by MICCP. By the addition of a low concentration of urea $\left(0-16 \mathrm{gL}^{-1}\right)$, up to $90 \%$ of the calcium ions was successfully removed from the examined wastewater.

The last 15 years have seen an increase in the types of contaminants to which bioremediation is being applied, including polychlorinated biphenyls (PCBs). Microbial processes are beginning to be used in the cleanup of these recalcitrant contaminants. The conventional methods of removing PCBs include solvent washing, hydroblasting, or sandblasting followed by encapsulation in epoxy coating. But all these treatments are quite inconvenient and ineffective due to resurfacing of the oil over time. An alternative to these is the use of carbonate biomineralizing bacterial isolates. Okwadha and Li (2010) recently reported the positive potential of ureolytic S. pasteurii cultures and urea/calcium for treatment of PCB - coated cement cylinders leading to surficial encapsulation of PCB containing oils.

\section{CARBON DIOXIDE SEQUESTRATION}

The exponentially growing concentrations of carbon dioxide in the environment invited researchers from worldwide to deal with the problem. Different ways were proposed to reduce the emission of $\mathrm{CO}_{2}$ into the atmosphere and earlier strategies developed were:

- Reduce its production and release into the atmosphere (by use of less carbon intensive energy sources like wind, solar and nuclear energy) 
- Increase efficiency of energy use from production to its end use.

But both these options were not possible practically, so researchers shifted to capturing/ sequestering the $\mathrm{CO}_{2}$ in a safe manner. Conversion of $\mathrm{CO}_{2}$ to carbonates offers the possibility of safe, stable and environmentally benign product for long term carbon sequestration, as massive carbonate mineral reservoirs have existed for millions of years. This option was looked upon by various researchers to capture and dispose the produced $\mathrm{CO}_{2}$ in a safe manner i.e., sequestration of $\mathrm{CO}_{2}$ (Herzog and Drake, 1996; Reichle et al., 1999; Shaffer, 2010; Sharma and Bhattacharya, 2010). This method includes fixing the $\mathrm{CO}_{2}$ in the form of carbonate minerals such as calcite, magnesite, and dolomite and came out to be safe and permanent method for disposing off the $\mathrm{CO}_{2}$ as the carbonate minerals are environmentally benign and stable. The proposed mechanism for reducing emissions is the capture and storage of $\mathrm{CO}_{2}$ in deep geologic reservoirs, such as deep saline aquifers. Leakage of $\mathrm{CO}_{2}$ back has also to be prevented which might be due to decreased well bore integrity and increased cap rock permeability (Barlet-Gouédard et al., 2009; Carey et al., 2010).

In nature, the sequestration of $\mathrm{CO}_{2}$ is based on the chemical fixation of $\mathrm{CO}_{2}$ in the form of carbonate minerals such as calcite, aragonite, dolomite and magnesite over a geological time scale. Scientists therefore proposed biomimetic $\mathrm{CO}_{2}$ sequestration by using biological catalysts like carbonic anhydrase (CA) to minimize the localized $\mathrm{CO}_{2}$ concentration. $\mathrm{CA}$ enzyme is ubiquitously distributed in organisms and fundamental to many eukaryotic biological processes like photosynthesis, respiration, $\mathrm{CO}_{2}$ and ion transport etc. (Smith and Ferry, 2000). Liu et al. (2005) used bovine $\mathrm{CA}$ as enzyme to accelerate $\mathrm{CO}_{2}$ hydration and reported that precipitation of calcium carbonate occurred much more quickly in presence of bovine CA. The role of biological CA in biological calcification of marine invertebrates (mollusks), fish otoliths, corals, hard tissues of vertebrates has been widely studied but applications of these microbes for $\mathrm{CO}_{2}$ sequestrations have started only recently (Beier and Anken, 2006; Tambutté et al., 2007).

MICCP serves as potential solution to seal fractures and high permeability leaking zones. The storage of $\mathrm{CO}_{2}$ is enhanced by MICCP by increasing the dissolved $\mathrm{CO}_{2}$ (as carbonate or bicarbonate) in the subsurface formation water or the precipitation of dissolved $\mathrm{CO}_{2}$ in carbonate minerals (Mitchell et al., 2010). Sequestration of $\mathrm{CO}_{2}$ by bacterial CA from different bacterial isolates has been recently shown by many (Ramanan et al., 2009; Wanjari et al., 2011; Yadav et al., 2011). Mitchell et al. (2010) and Phillips et al. (2013) proposed MICP to protect the well cements from supercritical $\mathrm{CO}_{2}$, plug microfractures near well environment and reduce the permeability in cap rock. Dupraz et al. (2009a,b) also investigated S. pasteurii in artificial groundwater to determine the transformation of $\mathrm{CO}_{2}$ into a solid carbonate phase (mineral trapping). Mitchell et al. (2010) demonstrated that as $\mathrm{pH}$ increases, the DIC increases and $\mathrm{CO}_{2}(\mathrm{~g})$ decreases. It was concluded that ureolysis-driven MICCP in the subsurface can potentially increase the security of long-term $\mathrm{CO}_{2}$ storage. Kupriyanova et al. (2007) studied successful deposition of $\mathrm{CaCO}_{3}$ by extracellular CAs of $M$. chthonoplastes cyanobacterial cells. Recently Jansson and Northen (2010) reported potential employment of cyanobacteria for point-source carbon capture and sequestration. The cyanobacteria utilize solar energy through photosynthesis to convert carbon dioxide to recalcitrant calcium carbonate biominerals (Kamennaya et al., 2012).

\section{FILLER FOR RUBBER, PLASTICS AND INK}

Application of MICCP technique has been recently reported to produce a material that can be used as filler in rubber and plastics, fluorescent particles in stationery ink, and a fluorescent marker (Yoshida et al., 2010). The group isolated moderately thermophilic bacterium Geobacillus thermoglucosidasius from thermophilically composted organic waste. This bacterium catalyzes the formation of calcite crystals which harbor the property of fluorescence. The calcite crystals formed by G. thermoglucosidasius nucleation are excited by a wavelength interval of $260-400 \mathrm{~nm}$, and their emission wavelengths are from 350 to $600 \mathrm{~nm}$. The wide emission wavelength interval is a novel fluorescence property of G. thermoglucosidasius catalyzed calcite crystals which encourages it usage as filler in rubber and plastics, fluorescent particles in stationery ink, and fluorescent marker. In materials engineering, environmentally friendly systems with minimal energy consumption and resource depletion are required for producing materials and composites. Biological processes serve as impressive archetypes of sustainable materials technologies. Because of the potential benefits of biominerals in this regard, its study has gained recognition as an important area of biomimetic materials science (Wakayama et al., 2005).

\section{BIOMINERALIZED CARBONATES IN CONSTRUCTION MATERIALS}

The potential of MICCP technology in restoration of cement mortar cubes, sand consolidation and limestone monument repair, reduction of water and chloride ion permeability in concrete, filling of pores and cracks in concrete, enhanced strength of bricks via urea hydrolysis pathway has been investigated by many researchers (Ramakrishnan, 2007; Sarda et al., 2009; Al Qabany, 2011; Chu et al., 2011; Dhami et al., 2012a; Cheng et al., 2013 and references within).

\section{BIODEPOSITION IN SOIL AND SAND MATERIALS}

Mechanical properties of soil are often insufficient and subjected to erosion. Stabilization of soil is highly desirable because of the increasing infrastructure. Conventional chemical grouting techniques are often expensive and require many injection wells for treating large volumes. Recently, the techniques which aims at changing soil properties on demand by stimulating natural (bio-) chemical processes in situ has been found and called as biogrouting i.e., in situ soil strengthening technique, involving microbial induced carbonate precipitation (Van Meurs et al., 2006; Whiffin et al., 2007; Ivanov and Chu, 2008). In this case, reagents and catalysts are injected and transported to the location where strengthening is required. Many researchers have evaluated the potential of application of bacterially induced carbonate precipitation by ureolytic bacteria by providing urea and calcium sources in various sand plugs (Stocks-Fischer et al., 1999; Bachmeier et al., 2002; Dick et al., 2006; Whiffin et al., 2007; Achal et al., 2009b; Van 
Paassen, 2009; Van Paassen et al., 2010). Kantzas et al. (1992) reported that sand consolidation by $B$. pasteurii reduced porosity by up to $50 \%$ and permeability by up to $90 \%$ in the areas where the cementation took place. Improvement in strength of sand columns upon bacterial carbonates was also reported (Ferris and Stehmeier, 1992; DeJong et al., 2006; Whiffin et al., 2007). Recent research initiatives have shown that the calcite crystals form cohesive "bridges" between existing sand grains, increasing the stiffness of sand with limited decrease in permeability (Mitchell and Santamarina, 2005; DeJong et al., 2006; Whiffin et al., 2007; Ivanov and Chu, 2008; Van Paassen et al., 2010; Al Qabany, 2011) (Figure 4). Ureolytic driven MICCP has also been proposed to suppress dust, reduce permeability in granular media, improve soils, stabilize slopes and strengthen liquefiable soils (Gollapudi et al., 1995; Ferris et al., 1996; Whiffin et al., 2007; Bang et al., 2011; Burbank et al., 2011). Harkes et al. (2010) reported the successful potential of MICCP in soil for ground reinforcement. Burbank et al. (2011) subjected the soils on shore Snake river (USA) with ureolytic biomineralization treatments and found around $1 \% \mathrm{CaCO}_{3}$ in near surface and $1.8-2.4 \%$ calcite below $90 \mathrm{~cm}$. Chu et al. (2012) also found considerable reduction in permeability and improvement in shear strength of soil upon application of ureolytic bacterial sp. isolated from tropical beach sand. In the studies of Stabnikov et al. (2011), halotolerant, alkaliphilic Bacillus sp. VS1 successfully sealed a sand-lined model pond. Successive percolation treatments with high concentrations of urea and calcium solutions resulted in a nearly impermeable crust on the surface of the sand, which markedly reduced the seepage rate. Bang et al. (2011) recently showed the potential of MICCP by ureolytic bacteria to suppress dust.

\section{BIOMINERALIZATION IN CEMENTITIOUS MATERIALS}

The successful application of bacterial biomineral calcite for improving the compressive strength of mortar and concrete has been reported by several studies (Bang et al., 2001; Ramachandran, 2001; Ghosh et al., 2005; De Muynck et al., 2008a,b; Jonkers et al., 2010; Park et al., 2010; Achal et al., $2011 a, c)$. In all these works, different ureolytic bacteria have been applied (Table 2) and they all have improved the properties of cement concrete specimens to a considerable extent. Ramakrishnan et al. (1998) found increase in resistance of

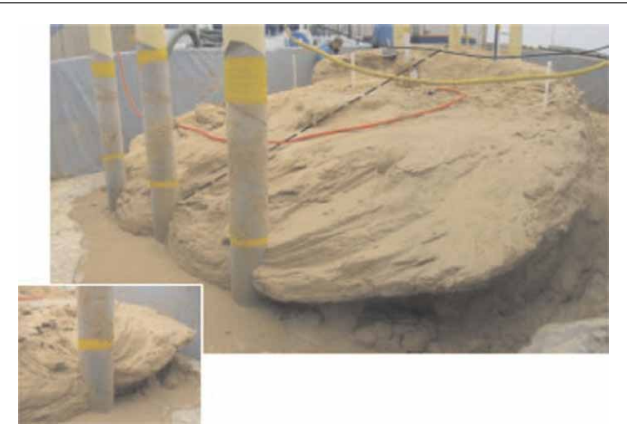

FIGURE 4 | Image of a cemented sand body from a large scale biogrout experiment. Van Paassen et al. (2010). concrete toward alkali, freeze thaw attack, drying shrinkage and reduction in permeability upon application of bacterial cells. De Muynck et al. (2008b) enhanced the permeability characteristics of mortar by B. sphaericus. Achal et al. (2011a) treated mortar cubes with Bacillus sp. CT-5 and reported nearly six times less absorption of water as compared to untreated specimens. They also studied the effect of $B$. pasteurii on water impermeability in concrete cubes and found the reduction in penetration of water which was more significant on the top side as compared to sides because of better compaction and closing of pores at the top surface (Achal et al., 2011a).

\section{REMEDIATION OF CRACKS IN CONCRETE}

In case of sealing the cracks in concrete structures, biomineralized $\mathrm{CaCO}_{3}$ has proved its efficacy in many reports (Gollapudi et al., 1995; Stocks-Fischer et al., 1999). Bang and Ramakrishnan (2001) used B. pasteurii for microbiologically enhanced crack remediation. Similar work was carried out by Ramachandran (2001) who also supported microbiological remediation of cracks in concrete. Bang et al. (2001) encapsulated ureolytic bacterial cells in polyurethanes (PU) and reported positive potential of microbiologically enhanced crack remediation by PU immobilized bacterial cells. De Belie and De Muynck (2008) also reported positive potential of biomineralized calcite in crack repair of concrete by B. sphaericus. Qian et al. (2010) reported that compressive strength of biomineralized specimens could be restored to $84 \%$. Recently Achal et al. (2013) reported the positive potential of bacterial calcite in crack remediation by Bacillus sp. CT-5.

Table 2 | Overview of different applications where microbial calcite is used as biocement in cementitious materials.

\begin{tabular}{llll}
\hline Application & Organism & Solution & Author \\
\hline $\begin{array}{lll}\text { Cement } \\
\text { mortar }\end{array}$ & Bacillus cereus & Nutrical & $\begin{array}{l}\text { Calcite bioconcept } \\
\text { Le Metayer-Levrel } \\
\text { et al., 1999 }\end{array}$ \\
& & & $\begin{array}{l}\text { Stocks-Fischer } \\
\text { et al., 1999; } \\
\end{array}$ \\
\cline { 2 - 4 } & Bacillus pasteurii & SF & Ramachandran, \\
& & 2001 \\
\end{tabular}

\begin{tabular}{|c|c|c|c|}
\hline \multirow[t]{4}{*}{$\begin{array}{l}\text { Remediation } \\
\text { of cracks in } \\
\text { concrete }\end{array}$} & Bacillus sphaericus & $\begin{array}{l}\text { Growth and } \\
\text { biocementation } \\
\text { medium }\end{array}$ & $\begin{array}{l}\text { De Belie and De } \\
\text { Muynck, } 2008\end{array}$ \\
\hline & Bacillus pasteurii & SF & $\begin{array}{l}\text { Ramachandran, } \\
2001\end{array}$ \\
\hline & Shewanella & Sterile & Ghosh et al., 2005 \\
\hline & $\begin{array}{l}\text { Sporosarcina } \\
\text { pasteurii }\end{array}$ & $\begin{array}{l}\text { CSL urea medium, } \\
\text { LML urea medium } \\
\text { NB urea medium }\end{array}$ & $\begin{array}{l}\text { Mukherjee et al., } \\
2010\end{array}$ \\
\hline Self-healing & $\begin{array}{l}\text { Bacillus } \\
\text { pseudifirmus } \\
\text { Bacillus cophnii }\end{array}$ & Calcium lactate & Jonkers, 2007 \\
\hline
\end{tabular}




\section{RESTORATION OF LIMESTONE BUILDINGS}

MICCP has also been studied for its efficacy in reducing the permeation properties and thereby leading to enhancing the durability of stone specimens by various researchers (Le Metayer-Levrel et al., 1999; Rodriguez-Navarro et al., 2003; Dick et al., 2006). Overview of different methodologies for deposition of microbial calcite layer on stone surfaces is given in Table 3 .

It was found that bacterially induced carbonates efficiently reduced the water sorptivity of the treated stone (Le MetayerLevrel et al., 1999). Rodriguez-Navarro et al. (2003) found that application of $M$. xanthus induces the precipitation of carbonates, phosphates and sulfates in a wide range of solid and liquid media (González-Munoz et al., 1993, 1996; Ben Omar et al., 1995, 1998; Ben Chekroun et al., 2004; Rodriguez-Navarro et al., 2007). Carbonate cementation by this bacterial isolate is successful up to a depth of several hundred micrometers $(>500 \mu \mathrm{m})$ without any plugging or blocking of the pores. Tiano et al. (1999) investigate the consolidating effect of bacterial biomineral calcite on Pietra di Lecce bioclastic limestone by use of Micrococcus sp. and B. subtilis. Dick et al. (2006) also reported 50\% reduction in water absorption by application of $B$. sphaericus to limestone cubes. The use of carbogel as a delivery system for bacteria for applications in limestone specimens was proposed by Cappitelli et al. (2006a). Zamarreno et al. (2009) investigated the application of calcite crystals precipitated by fresh water bacteria on limestone and found significant reduction in pore sizes of the substrate in treated specimens. De Muynck et al. (2013) reported B. sphaericus to be very efficient strain for consolidation of limestone specimens at range of temperatures $\left(10,20,28,37^{\circ} \mathrm{C}\right)$. This isolate led to $64 \%$ lower weight loss upon sonication and $46 \%$ decreased sorptivity in treated limestone specimens compared to the control specimens. De Muynck et al. (2011) recently applied bacterial calcite in two types of stones: microporous and macroporous. They reported that application of bacterial carbonates is more successful in macroporous stone where it occurs to a larger extent and at greater depths than in microporous stone.

\section{RESCUE OF BUILDINGS OF HISTORICAL INTEREST}

Increasing environmental pollution in many areas has been endangering the survival of carbonate stones of historic importance. Architectural and sculptural stones have been seen to undergo deterioration due to several physical, chemical, and biological weathering (Rodriguez-Navarro and Sebastian, 1996; Wakefield and Jones, 1998; Rodriguez-Navarro and Doehne, 1999). A classic example of art under threat was found in the cave of Lascaux in southwest France where devastating infection of Fusarium fungus and other molds covered the floor and banks of the main decorated chamber (Rosenbaum, 2006).

Table 3 | Overview of different methodologies where microbial calcite has been deposited as a layer on surface of stone.

\begin{tabular}{|c|c|c|c|c|}
\hline \multicolumn{2}{|l|}{ Experimental methods } & \multicolumn{2}{|c|}{ Application procedure } & \multirow[t]{2}{*}{ Authors } \\
\hline Inoculum & Bacteria & Nutrients & Evaluation procedures & \\
\hline $\begin{array}{l}\text { Culture in exponential } \\
\text { phase: } 10^{7} \text { to } 10^{9} \text { cells } / \mathrm{ml}\end{array}$ & Spraying & Spraying (5 times) & $\begin{array}{l}\text { Water absorption, SEM analysis, } \\
\text { surface roughness, colorimetery and } \\
\text { plate count }\end{array}$ & $\begin{array}{l}\text { Calcite bioconcept Le } \\
\text { Metayer-Levrel et al., } \\
1999\end{array}$ \\
\hline $\begin{array}{l}\text { Overnight culture } 10^{6} \text { cells } \\
\mathrm{cm}^{-2}\end{array}$ & $\begin{array}{l}\text { Brushing on water } \\
\text { saturated specimens }\end{array}$ & $\begin{array}{l}\text { Wetting every day for } \\
15 \text { days }\end{array}$ & $\begin{array}{l}\text { Water absorption, colorimeteric } \\
\text { measurements, stone cohesion }\end{array}$ & Tiano et al., 1999 \\
\hline $2 \%$ Inoculums & $\begin{array}{l}\text { Immersion in growing } \\
\text { bacterial culture (shaking or } \\
\text { stationary conditions) for } 30 \\
\text { days }\end{array}$ & & $\begin{array}{l}\text { Stone cohesion, weight increase, } \\
\text { XRD and SEM analysis, porosimetery } \\
\text { analysis }\end{array}$ & $\begin{array}{l}\text { Rodriguez-Navarro et al., } \\
2003\end{array}$ \\
\hline $1 \%$ Inoculums & $\begin{array}{l}\text { Immersion in growing } \\
\text { bacterial culture } \\
\text { (intermediate wetting) for } \\
28 \text { days }\end{array}$ & & Water absorption, SEM analysis & Dick et al., 2006 \\
\hline $10^{8}$ cells $\mathrm{ml}^{-1}$ & Spraying & In Carbogel & $\begin{array}{l}\text { Water absorption and drying due to } \\
\text { evaporation }\end{array}$ & May, 2005 \\
\hline n.d.* & n.d.* & $\begin{array}{l}\text { Immersion in test } \\
\text { solution or spraying } \\
\text { (in situ) tests }\end{array}$ & $\begin{array}{l}\text { Water absorption, colorimeteric } \\
\text { measurements, stone cohesion, } \\
\text { staining of newly formed calcite with } \\
\text { Alizarin Red S and Calcein }\end{array}$ & Tiano et al., 2006 \\
\hline $\begin{array}{l}\text { Overnight culture } 10^{7} \text { to } \\
10^{9} \text { cells } \mathrm{ml}^{-1}\end{array}$ & Immersion for 1 day & Immersion for 4 days & $\begin{array}{l}\text { Weight increase, water absorption, } \\
\text { gas permeability, chloride migration, } \\
\text { carbonation, freezing and thawing, } \\
\text { SEM and XRD analysis }\end{array}$ & De Muynck et al., 2008a \\
\hline
\end{tabular}

*n.d., not defined. 
Other paintings that shared the same fate were found in the Altamira cave in Santillana del Mar, Spain, and the earliest known Christian paintings that adorn Roman catacomb walls. To rescue these and other cultural testimonies, curators teamed up with the idea of recovery and consolidation of works of art by microbial biominerals (González and Saiz-Jiménez, 2005; Cappitelli et al., 2006b). Although microbes were the causative agents for deterioration, they served as the solution also. Several research groups reported that the anaerobic sulphate-reducing bacteria Desulfovibrio desulfuricans and D. vulgaris efficiently removed the black sulphate crusts that often tarnished buildings (Webster and May, 2006). Other studies reported that the bioformation of oxalic acid generates a protective calcium oxalate patina on stone surfaces (Garcia-Valles et al., 1997). Shewanella oneidensis MR1, also inhibited the rate of calcite dissolution under laboratory conditions (Lüttge and Conrad, 2004).

\section{IN LOW ENERGY BUILDING MATERIALS}

Construction sector is responsible for major input of energy resulting in large share of $\mathrm{CO}_{2}$ emissions into the atmosphere (Reddy and Jagadish, 2003). The emission of these greenhouse gases during manufacturing processes of building materials is contributing a lot to global warming. Its time to put emphasis on reducing the emission of these gases into the atmosphere and save energy by minimizing usage of conventional building materials, methods, techniques and working on some other

Table 4 | Energy in basic building materials (Reddy and Jagadish, 2003).

\begin{tabular}{ll}
\hline Type of material & Thermal energy $(\mathbf{M J} / \mathbf{~ k g})$ \\
\hline Cement & 5.85 \\
Lime & 5.63 \\
Lime Pozollana & 2.33 \\
Steel & 42 \\
Aluminium & 236.8 \\
Glass & 25.8 \\
\hline
\end{tabular}

substitutes. For reduction of indirect energy use in building materials, either alternative for bricks, steel and cement have to be found, or vigorous energy conservation measures in these segments of industry have to be initiated. Energy requirements for production and processing of different building materials, $\mathrm{CO}_{2}$ emissions and the implications on environment have been studied by many researchers (Oka et al., 1993; Debnath et al., 1995; Suzuki et al., 1995; Table 4).

Reddy and Jagadish (2003) reported soil cement blocks with 6$8 \%$ cement content to be most energy efficient building material. These materials have low cost, are easily recyclable and environmental friendly as the soils are mixed with additives like cement, lime etc. As there is no burning involved, this type of stabilized mud blocks help in conserving huge amounts in energy. Dhami et al. (2013b) successfully improved the durability of these low energy building materials by application of ureolytic Bacillus sp. This work indicates the potential of this technology for sustainable, cheap and durable buildings.

\section{INDUSTRIAL BYPRODUCT BUILDING MATERIALS}

As the traditional construction materials (such as concrete, bricks, hollow blocks, solid blocks, pavement blocks and tiles) are all produced from the existing natural resources and damaging the environment due to continuous exploration and depletion of natural resources, many researchers have looked for reusing the wastes in environmentally and economically sustainable ways (Aubert et al., 2006). Different types of wastes along with their recycling and utilization potentials are listed in Table 5.

Fly ash (FA) generated during the combustion of coal for energy production is one of the industrial byproduct that is recognized as an environmental pollutant. Rice husk ash (RHA) obtained from burning of rice husk is another major agricultural byproduct and available in all parts of the world except Antarctica (FAO, 2002). Both these materials can be used successfully in construction materials such as bricks and blocks without any degradation in the quality of products (Nasly and Yassin, 2009) but problems associated with ash bricks are low strength, higher water adsorption, low resistance to abrasion, low fire resistance and high porosity (Kumar and Palit, 1994). Dhami et al. (2012b) studied the

Table 5 | Different types and sources of solid wastes and their recycling and utilization potentials for construction materials (adapted from Pappu et al., 2007).

\begin{tabular}{|c|c|c|}
\hline Type of wastes & Source details & Recycling and utilization potentials \\
\hline Industrial waste (inorganic) & $\begin{array}{l}\text { Coal combustion residues, fly ash, steel slag, } \\
\text { construction debris }\end{array}$ & $\begin{array}{l}\text { Bricks, blocks, tiles, cement, paint, fine and coarse aggregates, } \\
\text { concrete, wood substitute products, ceramic products }\end{array}$ \\
\hline Agro waste (organic) & $\begin{array}{l}\text { Baggage, rice and wheat straw and husk, saw mill } \\
\text { waste, ground nut shell, jute, sisal, cotton stalk }\end{array}$ & $\begin{array}{l}\text { Cement boards, particle boards, insulation boards, wall panels, ro } \\
\text { sheets, binder, fibrous building panels, bricks, acid proof cement, } \\
\text { coir fiber, reinforced composites, polymer composites }\end{array}$ \\
\hline Mining/ mineral wastes & $\begin{array}{l}\text { Coal washeries waste, mining waste tailing from } \\
\text { iron, copper, zinc, gold industries }\end{array}$ & Bricks, fine and coarse lightweight aggregates, tiles \\
\hline Non-hazardous waste & $\begin{array}{l}\text { Waste gypsum, lime sludge, lime stone waste, } \\
\text { broken glass and ceramics }\end{array}$ & $\begin{array}{l}\text { Blocks, bricks, cement clinker, hydraulic binder, fibrous gypsum } \\
\text { boards, gypsum plaster, super sulfated cement }\end{array}$ \\
\hline Hazardous waste & $\begin{array}{l}\text { Contaminated blasting materials, galvanizing } \\
\text { waste, metallurgical residues, sludge from waste }\end{array}$ & Boards, bricks, cement, ceramics, tiles \\
\hline
\end{tabular}

water and waste water treatment plants 
application of bacterial calcite on these ash bricks (FA and RHA) and found it to be very effective in reducing permeability and decreasing water absorption leading to enhanced durability of ash bricks.

\section{CHALLENGES AND ISSUES}

The field of biomineralization includes a multidisciplinary research involving experts from various fields. Though its potential has been suggested in a variety of sectors but several efforts need to be made to address key research and development questions necessary for commercial scale applications.

One of the disadvantages of microbial cementation method in comparison with chemical methods is that the microbial process is usually slower. This method is more complex than the chemical one as the microbial activity depends on many environmental factors including temperature, $\mathrm{pH}$, concentrations of donors and acceptors of electrons, concentrations and diffusion rates of nutrients and metabolites etc. Due to this complexity, its usage at large-scale has not been so encouraging. Other gaps with usage of calcinogenic microbes include inconvenient application procedures, development of other unwanted microbes as repeated application of nutrients conceivably permit their development, need for detailed microbial ecology studies in order to ascertain the effects of the introduction of new bacteria etc.

The economic limitation of use of laboratory grade nutrient sources in field applications also restricts the use of this technology in several cases. Successful commercialization of the technique requires economical alternatives of the medium ingredients that cost as high as $60 \%$ of the total operating costs (Kristiansen, 2001). Use of inexpensive materials as corn steep liquor (CSL) or lactose mother liquor (LML) may help to lower the cost of treatment (Achal et al., 2009a,b, 2010; Mitchell et al., 2010). Production of large volumes of reactants and cultures also makes this technology a bit inconvenient as compared to traditional treatments.

Production of ammonia during hydrolysis of urea poses environmental concern (toxic effects on human health, vegetation, atmospheric nitrogen deposition, leading to the eutrophication and acidification of sensitive ecosystems) as well as leads to discoloration of stone (Sutton et al., 2008; Tobler

\section{REFERENCES}

Achal, V., Mukerjee, A., and Reddy, M. S. (2013). Biogenic treatment improves the durability and remediates the cracks of concrete structures. Con. Build. Mat. 48, 1-5. doi: 10.1016/j.conbuildmat.2013.06.061

Achal, V., Mukherjee, A., and Reddy, M. S. (2010). Biocalcification by Sporosarcina pasteurii using Corn steep liquor as nutrient source. J. Ind. Biotechnol. 6, 170-174. doi: 10.1089/ind.2010.6.170

Achal, V., Mukherjee, A., and Reddy, M. S. (2011a). Microbial concrete: a way to enhance the durability of building structures. J. Mater. Civ. Eng. 23, 730-734. 5533.0000159

Achal, V., Pan, X., and Zhang, D. (2011b). Remediation of coppercontaminated soil by Kocuria flava CR1, based on microbially induced calcite precipitation. Ecol. Eng. 37, 1601-1605. doi: 10.1016/j.ecoleng.2011.06.008

Achal, V., Mukherjee, A., and Reddy, M. S. (2011c). Effect of calcifying bacteria on permeation properties of concrete structures. J. Ind. Microbiol. Biotechnol. 38, 1229-1234. doi: 10.1007/s10295-010-0901-8

Achal, V., Mukherjee, A., Basu, P. C., and Reddy, M. S. (2009a). doi: $\quad$ 10.1061/(ASCE)MT.1943-

et al., 2011). Additional research is necessary to overcome this problem and encourage the use of MICCP for production of biominerals.

The survival of bacteria within the building material also influences the extent of calcification. Detailed microbial ecology studies are imperative in order to ascertain the effects of the introduction of new bacteria into the natural microbial communities, the development of the communities at short, mid and longterm, and the eventual secondary colonization of heterotrophic microorganisms using bacterial organic matter and dead cells, such as actinomycetes, fungi, etc.

The above mentioned concerns limit the use of MICCP for practical applications in various fields in comparison to the traditional methods.

\section{CONCLUDING REMARKS AND SUGGESTIONS FOR FUTURE WORK}

Microbially induced biominerals by microbes are being used extensively these days in various fields ranging from removal of heavy metals and radionucleotides to remediation of building materials. The potential of these biominerals has brought a new revolution in various engineering applications but still there has been much to explore in order to bring this environmentally safe, cost effective and convenient technology from lab to field scales. More exploratory works at large scale should be undertaken to determine the efficacy of in situ biomineralization for sequestration of metals, $\mathrm{PCBs}, \mathrm{CO}_{2}$ sequestration as well as consolidations of buildings. Comparative studies should be done to check the feasibility of this method with that of the chemical methods which should include environmental impacts as well as cost. The optimal balance of substrates used for various applications should be looked upon to increase the economic feasibility and reduce the production of unwanted byproducts. Long term efficacy of these biominerals should be investigated. Efforts should also be made to improve current mathematical models for determining MICCP at macro-scales. As the successful implementation of MICCP-based technologies require experts of varying disciplines, researchers from all around the globe should work together to make this multi-disciplinary research move toward commercial scale applications at a higher pace.

Lactose mother liquor as an alternative nutrient source for microbial concrete production by Sporosarcina pasteurii. J. Ind. Microbiol. Biotechnol. 36, 433-438. doi: 10.1007/s10295-008-0514-7

Achal, V., Mukherjee, A., Basu, P. C., and Reddy, M. S. (2009b). Strain improvement of Sprosarcina pasteurii for enhanced urease and calcite production. J. Ind. Microbiol. Biotechnol. 36, 981-988. doi: 10.1007/s10295-009-0578-z

Achal, V., Pan, X., Fu, Q., and Zhang, D. (2012). Biomineralization based remediation of As(III) contaminated soil by Sporosarcina ginsengisoli. J. Hazard. Mater. 201,
178-184. doi: 10.1016/j.jhazmat. 2011.11.067

Al Qabany, A. (2011). Microbial Carbonate Precipation in Soils. Ph.D. Dissertation, University of Cambridge, Cambridge.

Arp, G., Reiner, A., and Reiner, J. (2001). Photosynthesis-induced biofilm calcification and calcium concentration in Phanerozoic oceans. Science 292, 1701-1704. doi: 10.1126/science.1057204

Aubert, J. E., Husson, B., and Sarramone, N. (2006). Utilization of municipal solid waste incineration (MSWI) fly ash in blended cement: part 1: processing and characterization of MSWI fly ash. 
J. Hazard. Mater. 136, 624-631. doi: 10.1016/j.jhazmat.2005.12.041

Bachmeier, K. L., Williams, A. E., Warmington, J. R., and Bang, S. S. (2002). Urease activity in microbiologically - induced calcite precipitation. J. Biotechnol. 93, 171-181. doi: 10.1016/S0168-1656(01)00393-5

Bang, S., Min, S. H., and Bang, S. S. (2011). Application of microbially induced soil stabalization technique for dust suppression. Int. J. Geo-Eng. 3, 27-37.

Bang, S. S., and Ramakrishnan, V. (2001). "Microbiologicallyenhanced crack remediation (MECR)," in Proceedings of the International Symposium on Industrial Application of Microbial Genomes, (Daegu), 3-13.

Bang, S. S., Galinat, J. K., and Ramakrishnan, V. (2001). Calcite precipitation induced by polyurethane-immobilized Sporosarcina pasteurii. Enzyme Microb. Tech. 28, 404-409. doi: 10.1016/S0141-0229(00)00348-3

Barlet-Gouédard, V., Rimmelé, G., Porcherie, O., Quisel, N., and Desroches, J. (2009). A solution against well cement degradation under $\mathrm{CO}_{2}$ geological storage environment. Int. J. Greenhouse Gas Control 3, 206-216. doi: 10.1016/j.ijggc.2008.07.005

Bäuerlein, E. (2003). Biomineralization of unicellular organisms: an unusual membrane biochemistry for the production of inorganic nano- and microstructures. Angew. Chem. Int. 42, 614-641. doi: 10.1002/anie.200390176

Beier, M., and Anken, R. (2006). On the role of carbonic anhydrase in the early phase of fish otolith mineralization. $A d v$. Space Res. 38, 1119-1122. doi: 10.1016/j.asr.2005.10.027

Ben Chekroun, K., Rodriguez-Navarro, C., Gonzalez-Muñoz, M. T., Arias, J. M., Cultrone, G., and RodriguezGallego, M. (2004). Precipitation and growth morphology of calcium carbonate induced by Myxococcus xanthus: implications for regognition of bacterial carbonates. J. Sedimentary Res. 74, 868-876. doi: 10.1306/050504740868

Ben Omar, N., González-Mu noz, M. T., and Pe nalver, J. M. A. (1998). Struvite crystallization on Myxococcus cells. Chemosphere 36, 475-481. doi: 10.1016/S0045-6535(97)10014-5

Ben Omar, N., Martínez-Ca namero, M., González-Mu noz, M. T., Maria Arias, J., and Huertas, F. (1995). Myxococcus xanthus killed cells as inducers of struvite crystallization Its possible role in the biomineralization processes. Chemosphere 30, 2387-2396. doi: 10.1016/0045-6535(95)00110-T

Benzerara, K., Menguy, N., LópezGarcía, P., Yoon, T. H., Kazmierczak, J., Tyliszczak, T., et al. (2006). Nanoscale detection of organic signatures in carbonate microbialites. Proc. Natl. Acad. Sci. U.S.A. 103， 9440-9445. doi: 10.1073/pnas.0603255103

Burbank, M. B., Weaver, T. J., Green, T. L., Williams, B. C., and Crawford, R. L. (2011). Precipitation of calcite by indigenous microorganisms to strengthen liquefiable soils. Geomicrobiol. J. 28, 301-312. doi: 10.1080/01490451.2010.499929

Cappitelli, F., Zanardini, E., Ranalli, G., Mello, E., Daffonchio, D., and Sorlini, C. (2006a). Improved methodology for bioremoval of black crusts on historical stone artworks by use of sulfate reducing bacteria. Appl. Environ. Microbiol. 72, 3733-3737. doi: 10.1128/AEM.72.5.3733-3737.2006 Cappitelli, F., Shashoua, Y., and Vassallo, E. (2006b). Macromolecules in cultural heritage. Macromol. Symp. 238, 1-104.

Carey, J. W., Svec, R., Grigg, R., Zhang, J., and Crow, W. (2010). Experimental investigation of well bore integrity and $\mathrm{CO} 2$-brine flow along the cement-casing annulus. Int. J. Greenhouse Gas Control 4, 272-282. doi: 10.1016/j.ijggc.2009.09.018

Castanier, S., Le Metayer-Levrel, G., and Perthuisot, J. P. (1999). Ca-carbonates precipitation and limestone genesis-the microbiogeologist point of view. Sediment. Geol. 126, 9-23. doi: 10.1016/S0037-0738(99)00028-7

Castanier, S., Le Metayer-Levrel, G., and Perthuisot, J. P. (2000). "Bacterial roles in the precipitation of carbonate minerals," in Microbial Sediments, eds R. E. Riding and S. M. Awramik (Heidelberg: Springer-Verlag), 32-39.

Chafetz, H. S., and Buczynski, C. (1992). Bacterally induced lithification of microbial mats. Palaios 7 , 277-293. doi: 10.2307/3514973

Chen, L., Shen, Y., Xie, A., Huang, B., Jia, R., Guo, R., et al. (2009). Bacteria mediated synthesis of metal carbonate minerals with unusual morphologies and structures. Cryst. Growth Des. 9, 743-754. doi: $10.1021 / \mathrm{cg} 800224 \mathrm{~s}$

Cheng, L., Cord-Ruwisch, R., and Shahin, M. A. (2013). Cementation of sand soil by microbially induced calcite precipitation at various degrees of saturation. Can. Geotech. J. 50, 81-90. doi: 10.1139/cgj-2012-0023

Chu, J., Ivanov, V., Naeimi, M., Li, B., and Stabnikov, V. (2011). "Development of microbial geotechnology in Singapore," in Proceedings of Geofrontiers 2011: Advances in Geotechnical Engineering (Dallas, TX: ASCE Geotechnical Special Publication 211), 4070-4078.

Chu, J., Stabnikov, V., and Ivanov, V. (2012). Microbially induced calcium carbonate precipitation on surface or in the bulk of soil. Geomicrobiol. J. 29, 544-549. doi: 10.1080/01490451.2011.592929

Colwell, F. S., Smith, R. W., Ferris, G. F., Reysenbach, A. L., Fujita, Y., Tyler, T. L., et al. (2005). "Microbially mediated subsurface calcite precipitation for removal of hazardous divalent cations, Chapter 6" in Subsurface Contamination Remediation, eds E. Berkey and T. Zachry (Washington, DC: American Chemical Society), 117-137. doi: 10.1021/bk-2005-0904.ch006

Cunningham, S. D., Berti, W. R., and Hung, J. W. (1995) Phytoremediation of contaminated soils. Trends Biotechnol. 13, 393-397. doi: 10.1016/S0167-7799 (00)88987-8

De Belie, N., and De Muynck, W. (2008). "Crack repair in concrete using biodeposition," in Proceedings of ICCRR (Cape Town).

De Jong, J. T., Fritzges, M. B., and Nusstein, K. (2006). Microbially induced cementation to control sand response to undrained shear. J. Geotech. Geoenviron. Eng. 132, 1381-1392. doi: 10.1061/(ASCE) 1090-0241(2006)132:11(1381)

DeJong, J. T., Mortensen, M. B., Martinez, B. C., and Nelson, D. C. (2010). Biomediated soil improvement. Ecol. Eng. 36, 197-210. doi: 10.1016/j.ecoleng.2008.12.029

De Muynck,W., Cox, K., De Belie, N., and Verstraete, W. (2008a). Bacterial carbonate precipitation as an alternative surface treatment for concrete. Constr. Build. Mater. 22, 875-885. doi: 10.1016/ j.conbuildmat.2006.12.011

De Muynck,W., Debrouwer, D. De Belie, N., and Verstraete,W. (2008b). Bacterial carbonate precipitation improves the durability of cementitious materials. Cem. Concr. Res.38, 1005-1014. doi: $\quad 10.1016 /$ j.cemconres.2008. 03.005

De Muynck, W., Leuridan, S., Van Loo, D., Verbeken, K., Cnudde, V., De
Belie, N., et al. (2011). Influence of pore structure on the effectiveness of a biogenic carbonate surface treatment for limestone conservation. Appl. Environ. Microbiol. 77, 6808-6820. doi: 10.1128/AEM. 00219-11

De Muynck, W., Verbeken, K., De Belie, N., and Verstraete, W. (2013). Influence of temperature on the effectiveness of a biogenic carbonate surface treatment for limestone conservation. Appl. Microbiol. Biotechnol. 97, 1335-1347. doi: 10.1007/s00253-012-3997-0

Debnath, A., Singh, S. V., and Singh, Y. P. (1995). Comparative assessment of energy requirements for different types of residential buildings in India. Energy Build. 23, 141-146. doi: 10.1016/0378-7788 (95)00939-6

Decho, A. W. (2009). Overview of biopolymer-induced mineralization: what goes on in biofilms? Ecol. Eng. 30, 1-8.

Dhami, N. K., Mukherjee, A., and Reddy, M. S. (2012a). "Biofilm and microbial applications in biomineralized concrete," in Advanced topics in Biomineralization, ed Jong Seto (New York, NY: InTech), 137-164.

Dhami, N. K., Mukherjee, A. and Reddy, M. S. (2012b). Improvement in strength properties of ash bricks by bacterial calcite. Ecol. Eng. 39, 31-35. doi: 10.1016/j.ecoleng.2011.11.011

Dhami, N. K., Mukherjee, A., and Reddy, M. S. (2013a). Biomineralization of calcium carbonate polymorphs by the bacterial strains isolated from calcareous sites. J. Microbiol. Biotechnol. 23, 707-714. doi: 10.4014/jmb.1212.11087

Dhami, N. K., Mukherjee, A., and Reddy, M. S. (2013b). Bacillus megaterium mediated mineralization of calcium carbonate as biogenic surface treatment of green building materials. World J. Microbiol. Biotechnol. doi: 10.1007/ s11274-013-1408-z. [Epub ahead of print].

Dick, J., De Windt, W., De Graef, B., Saveyn, H., Van der Meeren, P. De Belie, N., et al. (2006). Biodeposition of a calcium carbonate layer on degraded limestone by Bacillus species. Biodegradation 17, 357-367. doi: 10.1007/s10532-0059006-x

Douglas, S., and Beveridge, T. J. (1998). Mineral formation by bacteria in natural microbial communities. FEMS Microbiol. Ecol. 26, 79-88. doi: $\quad 10.1111 /$ j.1574-6941.1998. tb00494.x 
Dupraz, S., Menez, B., Gouze, P., Leprovost, R., Benezeth, P., Pokrovsky, O., et al. (2009a). Experimental approach of $\mathrm{CO}_{2}$ biomineralization in deep saline aquifers. Chem. Geol. 265, 54-62. doi: 10.1016/j.chemgeo.2008.12.012

Dupraz, S., Parmentier, M., Menez, B., and Guyot, F. (2009b). Experimental and numerical modeling of bacterially induced $\mathrm{pH}$ increase and calcite precipitation in saline aquifers. Chem. Geol. 265, 44-53. doi: 10.1016/j.chemgeo.2009.05.003

Ehrlich, H. L. (1996). How microbes influence mineral growth and dissolution. Chem. Geol.132, 5-9. doi: 10.1016/S0009-2541(96)00035-6

Ercole, C., Cacchio, P., Botta, A. L., Centi, V., and Lepidi, A. (2007). Bacterially induced mineralization of calcium carbonate: the role of exopolysaccharides and capsular polysaccharides. Microsc. Microanal. 13, 42-50. doi: $10.1017 /$ S1431927607070122

FAO. (2002). Statistical Database. Available online at: http://apps.fao. org

Ferris, F. G., and Stehmeier, L. G. (1992). Bacteriogenic Mineral Plugging, United States Patent 5143155.

Ferris, F. G., Stehmeier, L. G., Kantzas, A., and Mourits, F. M. (1996). Bacteriogenic mineral plugging. J. Can. Petrol. Technol. 35, 56-61. doi: 10.2118/96-08-06

Folk, R. (1993). SEM imaging of bacteria and nanobacteria in carbonate sediments and rocks. J. Sedim. Petrol. 63, 990-999.

Fortin, D., Ferris, F. G., and Beveridge, T. J. (1997). Surface-mediated mineral development by bacteria. Rev. Mineral. 35, 161-180.

Fujita, Y., Ferris, F. G., Lawson, R. D., Colwell, F. S., and Smith, R. W. (2000). Calcium carbonate precipitation by ureolytic subsurface bacteria. Geomicrobiol. J. 17, 305-318. doi: 10.1080/782198884

Fujita, Y., Redden, G. D., Ingram, J. C., Cortez, M. M., Ferris, F. G., and Smith, R. W. (2004). Strontium incorporation into calcite generated by bacterial ureolysis. Geochim. Cosmochim. Acta. 68, 3261-3270. doi: 10.1016/j.gca.2003.12.018

Fujita, Y., Taylor, J., Wendt, L., Reed, D., and Smith, R. (2010). Evaluating the potential of native ueolytic microbes to remediate $\mathrm{Sr}$ contaminated environment. Environ. Sci. Technol. 44, 7652-7658. doi: 10.1021/ es $101752 \mathrm{p}$

Fujita, Y., Taylor, J. L., Gresham, T., Delwiche, M., Colwell, F., Mc
Ling, T., et al. (2008). Stimulation of microbial urea hydrolysis in groundwater to enhance calcite precipitation. Environ. Sci. Technol. 42, 3025-3032. doi: $10.1021 /$ es702643g

Garcia-Valles, M., Vendrell-Saz, M. Krumbein, W. E., and Urzi, C. (1997). Coloured mineral coatings on monument surfaces as a result of biomineralisation: the case of Tarragona Cathedral (Catalonia). Appl. Geochem. 12, 255-266. doi: 10.1016/S0883-2927(96)00057-1

Gebauer, D., Gunawidjaja, P. N., Ko, J. Y. P., Bacsik, S., Aziz, B., Liu, L., et al. (2010). Proto-calcite and proto-vaterite in amorphous calcium carbonates. Angew. Chem. Int. Ed. 49, 8889-8891. doi: 10.1002/anie.201003220

Ghosh, P., Mandal, S., Chattopadhyay, B. D., and Pal, S. (2005). Use of microorganisms to improve the strength of cement mortar. Cem. Concr. Res. 35, 1980-1983. doi: 10.1016/j.cemconres.2005.03.005

Gollapudi, U. K., Knutson, C. L., Bang, S. S., and Islam, M. R. (1995). A new method for controlling leaching through permeable channels. Chemosphere 30, 695-705. doi: $\quad 10.1016 / 0045-6535(94)$ 00435-W

González, J. M., and Saiz-Jiménez, C. (2005). Application of molecular nucleic acid-based techniques for the study of microbial communities in monuments and artworks. Int Microbiol 8, 189-194.

González-Munoz, M. T., Omar, N. B., Martínez-Ca namero, M., Rodríguez-Gallego, M., Galindo, A. L., and Arias, J. (1996). Struvite and calcite crystallization induced by cellular membranes of Myxococcus xanthus. J. Cryst. Growth 163, 434-439. doi: 10.1016/0022-0248(95)01011-4

González-Muñoz, M. T., RodriguezNavarro, C., Martínez-Ruiz, F., Arias, J. M., Merroun, M. L., and Rodriguez-Gallego, M. (2011). Bacterial biomineralization: new insights from Myxococcus - induced mineral precipitation. Geol. Soc. Lond. Sp. Pub. 336, 31-50. doi: 10.1144/SP336.3

González-Munoz, M., Arias, J. M., Montoya, E., and RodriguezGallego, M. (1993). Struvite production by Myxococcus coralloides D. Chemosphere 26, 1881-1887. doi: 10.1016/0045-6535 (93)90081-F

Gower, L. B. (2008). Biomimetic model systems for investigating the amorphous precursor pathway and its role in biomineralization.
Chem. Rev. 108, 4551-4627. doi: $10.1021 / \mathrm{cr} 800443 \mathrm{~h}$

Hammes, F. (2002). Ureolytic Microbial Calcium Carbonate Precipitation. Ph.D. Thesis, Ghent University, Ghent.

Hammes, F., Boon, N., De Villiers, J., Verstraete, W., and Siciliano, S. D. (2003). Strain-specific ureolytic microbial calcium carbonate precipitation. Appl. Environ. Microbiol. 69, 4901-4909. doi: 10.1128/AEM.69.8.4901-4909.2003

Hammes, F., and Verstraete,W. (2002). Key roles of $\mathrm{pH}$ and calcium metabolism in microbial carbonate precipitation. Rev. Environ. Sci. Biotechnol. 1, 3-7. doi: 10.1023/A:1015135629155

Harkes, M. P., van Paassen, L. A. Booster, J. L., Whiffin, V. S., and van Loosdrecht, M. C. M. (2010). Fixation and distribution of bacterial activity in sand to induce carbonate precipitation for ground reinforcement. Ecol. Eng. 36, 112-117. doi: 10.1016/j.ecoleng.2009.01.004

Herzog, H. J., and Drake, E. M. (1996). Carbon dioxide recovery and disposal from large energy systems. Annu. Rev. Energy Environ. 21, 145-166. doi: 10.1146/annurev.energy.21.1.145

Ivanov, V., and Chu, J. (2008). Applications of microorganisms to geotechnical engineering for bioclogging and biocementation of soil in situ. Rev. Environ. Sci. Biotechnol. 7, 139-153. doi: 10.1007/s11157007-9126-3

Jansson, C., and Northen, T. (2010). Calcifying cyanobacteria-the potential of biomineralization for carbon capture and storage. Curr. Opin. Biotechnol. 21, 365-371. doi: 10.1016/j.copbio.2010.03.017

Jonkers, H. (2007). "Self healing concrete: a biological approach," in Self Healing Materials: An alternative Approach to 20 Centuries of Materials Science, ed S. van der Zwaag (Springer), 195-204. doi: 10.1007/978-1-4020-6250-6 9

Jonkers, H. M., Thijssen, A., Muyzer, G., Copuroglu, O., and Schlangen, E. (2010). Application of bacteria as self-healing agent for the development of sustainable concrete. Ecol. Eng. 36, 230-235. doi: 10.1016/j.ecoleng.2008.12.036

Kamennaya, N. A., Caroline, M. Ajo-Franklin., Trent, N., and Christer, J. (2012). Cyanobacteria as Biocatalysts for Carbonate Mineralization. Minerals 2, 338-364. doi: 10.3390/min2040338

Kantzas, A., Ferris, F. G., Jha, K. N., and Mourits, F. M. (1992).
"A novel method of sand consolidation through bacteriogenic mineral plugging," in Proceedings of CIM Annual Technical Conference, (Calgary, AB).

Keefe, W. E. (1976). Formation of crystalline deposits by several genera of the family Enterobacteriaceae. Infect. Immun. 14, 590-592.

Knorre, H., and Krumbein, K. E. (2000). "Bacterial calcification," in Microbial Sediments, eds E. E. Riding and S. M. Awramik (Berlin: Springer-Verlag), 25-31.

Kristiansen, B. (2001). "Process economics," in Biotechnology, 2nd Edn., eds C. Ratledge and B. Kristiansen (Cambridge: Cambridge University Press).

Krumbein, W. E. (1974). On the precipitation of aragonite on the surface of marine bacteria. Naturwissenchaften 61, 167. doi: 10.1007/BF00602591

Krumbein, W. E. (1979). Photolithotrophic and chemoorganotrophic activity of bacteria and algae as related to beach rock formation and degradation (Gulf of Aqaba, Sinai).Geomicrobiol. J. 1, 139-203. doi: 10.1080/01490457909377729

Kumar, D., and Palit, A. (1994). Proceedings of American Power Conference. Chicago: Illinois Institute of Technology.

Kupriyanova, E., Villarejo, A., Markelova, A., Gerasimenko, L., Zavarzin, G., Samuelsson, G., et al. (2007). Extracellular carbonic anhydrases of the stromatolite-forming cyanobacterium Microcoleus chthonoplastes. Microbiology. 153, 1149-1156. doi: 10.1099/mic.0.2006/003905-0

Kurmaç, Y. (2009). The impact of toxicity of metals on the activity of ureolytic mixed culture during the precipitation of calcium. J. Hazard. Mater. 163, 1063. doi: 10.1016/j.jhazmat.2008.07.061

Le Metayer-Levrel, G., Castanier, S., Orial, G., Loubiere, J. F., and Perthuisot, J. P. (1999). Applications of bacterial carbonatogenesis to the protection and regeneration of limestones in buildings and historic patrimony. Sediment. Geol. 126, 25-34. doi: 10.1016/S00370738(99)00029-9

Lian, B., Hu, Q., Chen, J., Ji, J., and Teng, H. H. (2006). Carbonate biomineralization by soil bacterium Bacillus megaterium. Geochim. Cosmochim. Acta 70, 5522-5535. doi: 10.1016/j.gca.2006.08.044

Lippmann, F. (1973). Sedimentary Carbonate Minerals. Berlin: Springer-Verlag. 10.1007/978-3-642-65474-9 
Liu, N., Bond, G. M., Abel, A., McPherson, B. J., and Stringer, J. (2005). Biomimetic sequestration of $\mathrm{CO}_{2}$ in carbonate form: Role of produced waters and other brines. Fuel Processing Technology 86, 1615-1625. doi: 10.1016/j.fuproc.2005.01.008

Lowenstam, H. A. (1981). Minerals formed by organisms. Science 211, 1126-1131. doi: 10.1126/science.7008198

Lowenstam, H. A., and Weiner, S. (1989). On Biomineralization. New York, NY: Oxford University Press.

Lüttge, A., and Conrad, P. G. (2004). Direct observation of microbial inhibition of calcite dissolution. Appl. Environ. Microbiol. 70, 1627-1632. doi: 10.1128/AEM.70.3.1627-1632.2004

May, E. (2005). Biobrush Research Monograph: Novel Approaches to Conserve our European heritage. EVK4-CT-2001-00055

Mc Connaughey, T. A., and Whelan, J. F. (1997). Calcification generates protons for nutrient and bicarbonate uptake. Earth Sci. Rev. 42, 95-117. doi: 10.1016/S0012-8252(96)00036-0

McKay, D. S., Gibson, E. K., ThomasKeprta, K. L., Vali, H., Romanek, C. S., Clement, S., et al. (1996). Search for past life on mars: possible relic biogenic activity in Martian meteorite ALH84001. Science 273, 924-930. doi: 10.1126/science.273.5277.924

Meldrum, F., and Cölfen, H. (2008). Controlling mineral morphologies and structures in biological and synthetic systems. Chem. Rev. 108, 4332-4432. doi: 10.1021/cr8002856

Mitchell, A. C., Dideriksen, K., Spangler, L., Cunningham, A., and Gerlach, R. (2010). Microbially enhanced carbon capture and storage by mineral-trapping and solubility-trapping. Environ. Sci. Technol. 44, 5270-5276. doi: $10.1021 /$ es $903270 \mathrm{w}$

Mitchell, A. C., and Ferris, F. G. (2006). The influence of Bacillus pasteurii on the nucleation and growth of calcium carbonate. Geomicrobiol. J. 23, 213-226. doi: 10.1080/01490450 600724233

Mitchell, J. K., and Santamarina, J. C. (2005). Biological considerations in geotechnical engineering. J. Geotech. Geoenviron. Eng. 131, 1222-1233. doi: 10.1061/(ASCE) 1090-0241(2005)131:10(1222)

Mobley, H. L. T., and Hausinger, R. P. (1989). Microbial urease: Significance, regulation and molecular characterization. Microbiol. Rev. 53, 85-108.
Monger, H. C., Daugherty, L. A., Lindemann, W. C., and Liddell, C. M. (1991). Microbial precipitation of pedogenic calcite. Geology 19, 997-1000. doi: 10.1130/00917613(1991)019<0997:MPOPC>2. 3.CO;2

Morse, J. W. (1983). The kinetics of calcium carbonate dissolution and precipitation. Rev. Mineral. Geochem. 11, 227-264.

Mukherjee, A., Achal, V., and Reddy, M. S. (2010). In search of a sustainable binder in building materials. Ann. Ind. Acad. Eng. 7, 41-51.

Nasly, M. A., and Yassin, A. A. M. (2009). "Sustainable housing using an innovative interlocking block building system," in Proceedings of the Fifth National Conference on Civil Engineering (AWAM'09): Towards Sustainable Development (Kuala Lumpur), 130-138.

Oka, T., Suzuki, M., and Konnya, T. (1993). The estimation of energy consumption and amount of pollutants due to the construction of buildings. Energy Build. 19, 303-311. doi: 10.1016/0378-7788(93)90016-N

Okwadha, G., and Li, J. (2010). Optimum conditions for microbial carbonate precipitation. Chemosphere 81, 1143-1148. doi: 10.1016/j.chemosphere.2010.09.066

Pappu, A., Saxena, M., and Asolekar, S. R. (2007). Solid wastes generation in India and their recycling potential in building materials. Build. Environ. 42, 2311-2320. doi: 10.1016/j.buildenv.2006.04.015

Park, S.-J., Park, Y.-M., Chun, W.-Y., Kim, W.-J., and Ghim, S.-Y. (2010). Calcite-forming bacteria for compressive strength improvement in mortar. J. Microbiol. Biotechnol. 20, 782-788.

Pentecost, A., and Bauld, J. (1988). Nucleation of calcite on the sheaths of cyanobacteria using a simple diffusion cell. Geomicrobiol. J. 6, 129-135. doi: 10.1080/ 01490458809377830

Phillips, A. J., Lauchnor, E., Eldring, J., Esposito, R., Mitchell, A. C., Gerlach, R., et al. (2013). Potential $\mathrm{CO}_{2}$ leakage reduction through biofilm-induced calcium carbonate precipitation. Environ. Sci. Technol. 47, 142-149. doi: 10.1021/es301294q

Qian, C., Wang, R., Cheng, L., and Wang, J. (2010). Theory of microbial carbonate precipitation and its application in restoration of cement-based materials defects. Chin. J. Chem. 28, 847-857. doi: 10.1002/cjoc.201090156
Ramachandran, S. K. (2001). Remediation of concrete using micro-organisms. ACI Mater. J. $98,3$.

Ramakrishnan, V. (2007). "Performance characteristics of bacterial concrete-a smart biomaterial," in Proceedings of the First International Conference on Recent Advances in Concrete Technology (Washington, DC), 67-78.

Ramakrishnan, V., Bang, S. S., and Deo, K. S. (1998). "A novel technique for repairing cracks in high performance concrete using bacteria," in Proceedings of International Conference on High Performance High Strength Concrete (Perth, WA), 597-618.

Ramanan, R., Kannan, K., Sivanesan, S. D., Mudliar, S., Kaur, S., and Tripathi, A. K. (2009). Biosequestration of carbon dioxide using carbonic anhydrase enzyme purified from Citrobacter freundii. World J. Microb. Biot. 25, 981-987. doi: 10.1007/s11274-009-9975-8

Reddy, B. V. V., and Jagadish, K. S. (2003). Embodied energy of common and alternative building materials and technologies. Energy and Buildings 35, 129-137. doi: 10.1016/S0378-7788(01)00141-4

Reichle, D., Houghton, J., Kane, B., Ekmann, J., Benson, S., Clarke, J., et al. (1999). "Carbon sequestration research and development," in U.S. Department of Energy Report DOE/SC/FE-1.

Rieger, J., Frechen, T., Cox, G., Heckmann, W., Schmidt, C., and Thieme, J. (2007). Precursor structures in the crystallization precipitation processes of $\mathrm{CaCO}_{3}$ and control of particle formation by polyelectrolytes. Farad. Discuss. 136, 265-277. doi: 10.1039/ b701450c

Rivadeneyra, M. A., Delgado, R., Moral, A., Ferrer, M. R., and Ramos-Cormenzana, A. (1994). Precipitation of calcium carbonate by Vibrio spp. from an inland saltern. FEMS Microbiol. Ecol. 13, 197-204. doi: 10.1016/0168-6496 (94)90013-2

Rivadeneyra, M. A., Delgado, R., Quesada, E., and RamosCormenzana, A. (1991). Precipitation of calcium carbonate by Deleya halophila in media containing $\mathrm{NaCl}$ as sole salt. Cur. Microbiol. 22, 185-190. doi 10.1007/BF02092132

Rivadeneyra, M. A., Parraga, J., Delgado, R., Ramos-Cormenzana, A., and Delgado, G. (2004). Biomineralization of carbonates by Halobacillus trueperi in solid and liquid media with different salinities. FEMS Microbiol. Ecol. 48, 39-46. doi: 10.1016/j.femsec.2003.12.008

Rivadeneyra, M. A., RamosCormenzana, A., Delgado, G., and Delgado, R. (1996). Process of carbonate precipitation by Deleya halophila. Cur. Microbiol.32, 308-313. doi: $10.1007 / \mathrm{s} 002849900055$

Rivadeneyra, M. A. G., Delgado, A., Ramos-Cormenzana., and Delgado, R. (1998). Biomineralization of carbonates by Halomonas eurihalina in solid and liquid media with different salinities: crystal formation sequence. Res. Microbiol. 149, 277-287. doi: 10.1016/S0923-2508(98)80303-3

Rodriguez-Navarro, C., and Doehne, E. (1999). Salt weathering: influence of evaporation rate, supersaturation and crystallization pattern. Earth Surface Process. Landforms 24, 191-209. doi: 10.1002/(SICI) 1096-9837(199903)24:3<191::AIDESP942>3.0.CO;2-G

Rodriguez-Navarro, C., RodriguezGallego, M., Chekroun, K. B., and Gonzalez-Muñoz, M. T. (2003). Conservation of ornamental stone byMyxococcus xanthus-induced carbonate biomineralisation. Appl. Environ. Microbiol. 69, 2182-2193. doi: 10.1128/AEM.69.4.2182-2193.2003

Rodriguez-Navarro, C., JimenezLopez, C., Rodriguez-Navarro, A., González-Mu $\sim$ noz, M. T., and Rodriguez-Gallego, M. (2007). Bacterially mediated mineralization of vaterite. Geochim. Cosmochim. Acta 71, 1197-1213. doi: 10.1016/j.gca.2006.11.031

Rodriguez-Navarro, C., Jroundi, F., Schiro, M., Ruiz-Agudo, E., and González -Muñoz, M. T. (2012). Influence of substrate mineralogy on bacterial mineralization of calcium carbonate: Implications in stone conservation. Appl. Environ. Microbiol. 78, 4017-4029. doi: 10.1128/AEM.07044-11

Rodriguez-Navarro, C., and Sebastian, E. (1996). Role of particulate matter from vehicle exhaust on porous building stones (limestone) sulfation. Sci. Total Environ. 187, 79-91. doi: 10.1016/0048-9697(96)05124-8

Rosenbaum, L. (2006, June 13). Prehistoric artistry, real and recreated. The Wall Street Journal, p. D6.

Rusznyak, A., Akob, D. M., Nietzsche, S., Eusterhues, K., Totsche, K. U., Neu, T. R., et al. (2012). Calcite biomineralization by bacterial isolates from the recently 
discovered pristine karstic Herrenberg cave. Appl. Environ. Microbiol. 78, 1157-1167. doi: 10.1128/AEM.06568-11

Sánchez-Navas, A., Martín-Algarra, A., Rivadeneyra, M. A., Melchor, S., and Martín-Ramos, J. D. (2009). Crystal-growth behaviour in Ca$\mathrm{Mg}$ carbonate bacterial spherulites. Cryst. Growth Des. 9, 2690-2699. doi: $10.1021 / \mathrm{cg} 801320 \mathrm{p}$

Sarda, D., Choonia, H. S., Sarode, D. D., and Lele, S. S. (2009). Biocalcification by Bacillus pasteurii urease: a novel application. J. Ind. Microbiol. Biotechnol. 36, 1111-1115. doi: 10.1007/s10295-009-0581-4

Schleck, D. (1990). Treatment Technologies for Refinery Wastes and Waste Waters, National Petroleum Refiners Association (NRPA) Annual Meeting. San Antonio, TX.

Shaffer, G. (2010). Long-term effectiveness and consequences of carbon dioxide sequestration. Nat. Geosci. 3, 464-467. doi: 10.1038/ngeo896

Sharma, A., and Bhattacharya, A. (2010). Enhanced biomimetic sequestration of $\mathrm{CO}_{2}$ into $\mathrm{CaCO}_{3}$ using purified carbonic anhydrase from indigenous bacterial strains. J. Mol. Catal. B Enzymatic. 67, 122-128. doi: 10.1016/j.molcatb.2010.07.016

Smith, K. S., and Ferry, J. G. (2000). Prokaryotic carbonic anhydrases. FEMS Microbiol. Rev. 24, 335-366. doi: 10.1111/j.15746976.2000.tb00546.x

Smith, R. W., Fujita, Y., Ferris, G. F., Cosgrove, D. M., and Colwell, R. S. (2004). "Trace metals in groundwater and vadose zone calcite: in situ containment and stabilization of strontium and other divalent metals and radionuclides at arid west DOE sites," in Technical Report. USDOE Office of Science. OSTI ID: 839261.

Somasundaran, P., and Agar, G. E. (1967). The zero point of charge of calcite. J. Colloid Interface Sci. 24, 142-147. doi: 10.1016/00219797(67)90241-X

Stabnikov, V., Naeimi, M., Ivanov, V., and Chu, J. (2011). Formation of water-impermeable crust on sand surface using biocement. Cem. Concrete Res. 41, 1143-1149. doi: 10.1016/j.cemconres.2011.06.017

Stocks-Fischer, S., Galinat, J. K., and Bang, S. S. (1999). Microbiological precipitation of $\mathrm{CaCO}_{3}$. Soil Biol. Biochem. 31, 1563-1571. doi: 10.1016/S0038-0717(99)00082-6
Stumm,W., and Morgan, J. J. (1981). Aquatic Chemistry, 2nd Edn. NewYork, NY: John Wiley.

Sutton, M., Reis, S., and Baker, S. (2008). "Atmospheric ammonia: detecting emission changes and environmental impact," in Results of an Expert Workshop under the Convention on LongRange Transboundary Air Pollution (Springer), 490

Suzuki, M., Oka, T., and Okada, K. (1995). The estimation of energy consumption and $\mathrm{CO}_{2}$ emission due to housing construction in Japan. Energy Build. 22, 165-169. doi: $\quad 10.1016 / 0378-7788(95)$ 00914-J

Tambutté, S., Tambutté, E., Zoccola, D., Camaniti, N., Lotto, S., Moya, A., et al. (2007). Characterization and role of carbonic anhydrase in the calcification process of the azooxanthellate coral Tubastrea aurea. Mar. Biol. 151, 71-83. doi: 10.1007/s00227-0060452-8

Thomas-Keprta, K. L., McKay, D. S., Wentworth, S. J., Stevens, T. O., Taunton, A. E., Allen, C., et al. (1998). Bacterial mineralization patterns in basaltic aquifers: Implications for possible life in Martian meteorite ALH84001. Geology 26, 1031-1034. doi: 10.1130/0091-7613(1998)026<103 1:BMPIBA $>2.3 . \mathrm{CO} ; 2$

Tiano, P., Biagiotti, L., and Mastromei, G. (1999). Bacterial bio-mediated calcite precipitation for monumental stones conservation: methods of evaluation. J. Microbiol. Methods 36, 139-145. doi: 10.1016/S01677012(99)00019-6

Tiano, P., Cantisani, E., Sutherland, I., and Paget, J. M. (2006). Biomediated reinforcement of weathered calcareous stones. J. Cult. Herit. 7, 49-55. doi: 10.1016/ j.culher.2005.10.003

Tobler, D. J., Cuthbert, M. O., Greswell, R. B., Riley, M. S., Renshaw, J. C., Handley-Sidhu, S., et al. (2011). Comparison of rates of ureolysis between Sporosarcina pasteurii and an indigenous groundwater community under conditions required to precipitate large volumes of calcite. Geochim. Cosmochim. Acta. 75, 3290-3301. doi: 10.1016/j.gca.2011.03.023

Van Meurs, G., Van Der Zon, W., Lambert, J., Van Ree, D., Whiffn, V., and Molendijk, W. (2006). "The challenge to adapt soil properties," in Proceedings of the 5th ICEG:
Environ. Geotechnics: Opportunities, Challenges and Responsibilities for Environmental Geotechnics, Vol. 2, (Cardiff; Wales), 1192-1199.

Van Paassen, L. A. (2009). Biogrout: Ground Improvement by Microbially Induced Carbonate Precipitation. Ph.D. thesis. Delft: Delft University of Technology.

Van Paassen, L. A., Daza, C. M., Staal, M., Sorokin, D. Y., van der Zon, W., and van Loosdrecht, M. C. M. (2010). Potential soil reinforcement by biological denitrification. Ecol. Eng. 36, 68-75. doi: 10.1016/j.ecoleng. 2009.03.026

Vasconcelos, C., McKenzie, J. A., Bernaconi, S., Grujic, D., and Tien, A. J. (1995). Microbial mediation as a possible mechanism for natural dolomite formation at low temperatures. Nature 377, 220-222. doi: 10.1038/377220a0

Wakayama, H., Hall, S. R., and Mann, S. (2005). Fabrication of $\mathrm{CaCO}_{3}$ - biopolymer thin films using supercritical carbon dioxide. J. Mater. Chem. 15, 1134-1136. doi: 10.1039/b418569b

Wakefield, R. D., and Jones, M. S. (1998). An introduction to stone colonizing micro-organisms and biodeterioration of building stone. Q. J. Eng. Geol. 31, 301-313. doi: 10.1144/GSL.QJEG.1998.031.P4.03

Wanjari, S., Prabhu, C., Yadav, R., Satyanarayana, T., Labhsetwar, N., and Rayalu, S. (2011). Immobilization of carbonic anhydrase on chitosan beads for enhanced carbonation reaction. Proc. Biochem. 46, 1010-1018. doi: 10.1016/j.procbio.2011.01.023

Warren, L. A., Maurice, P. A., Parmar, N., and Ferris, F. G. (2001). Microbially mediated calcium carbonate precipitation: implications for interpreting calcite precipitation and for solid-phase capture of inorganic contaminants. Geomicrobiol. J. 18, 93-115. doi: 10.1080/0149045015 1079833

Webster, A., and May, E. (2006). Bioremediation of weatheredbuilding stone surfaces. Trends Biotechnol. 24, 256-260. doi: 10.1016/j.tibtech.2006.04.005

Whiffin, V. S. (2004). Microbial CaCO3 Precipitation for the Production of Biocement. Ph. D. thesis. Perth, WA: Murdoch University.

Whiffin, V. S., van Paassen, L., and Harkes, M. (2007). Microbial carbonate precipitation as a soil improvement technique. Geomicrobiol. J. 24, 417-423. doi: 10.1080/01490450701436505

Wu, Y. J., Ajo-Franklin, J. B., Spycher, N., Hubbard, S., Zhang, G., Williams, K., et al. (2011). Geophysical monitoring and reactive transport modeling of ureolytically driven calcium carbonate precipitation. Geochem. Trans. 12, 7. doi: 10.1186/1467-4866-12-7

Yadav, R., Labhsetwar, N., Kotwal, S., and Rayalu, S. (2011). Single enzyme nanoparticle for biomimetic $\mathrm{CO}_{2}$ sequestration. J. Nanopart. Res. 13, 263-271. doi: 10.1007/s11051-010-0026-z

Yoshida, N., Higashimura, E., and Saeki, Y. (2010). Catalytic biomineralization of fluorescent calcite by the thermophilic bacterium Geobacillus thermoglucosidasius. Appl. Environ. Microbiol. 75, 7322-7327. doi: 10.1128/AEM.01767-10

Zamarreno, D. V., Inkpen, R., and May, E. (2009). Carbonate crystals precipitated by freshwater bacteria and their use as a limestone consolidant. Appl. Environ. Microbiol. 75, 5981-5990. doi: 10.1128/AEM.02079-08

Conflict of Interest Statement: The authors declare that the research was conducted in the absence of any commercial or financial relationships that could be construed as a potential conflict of interest.

Received: 31 July 2013; accepted: 05 October 2013; published online: 29 October 2013.

Citation: Dhami NK, Reddy MS and Mukherjee A (2013) Biomineralization of calcium carbonates and their engineered applications: a review. Front. Microbiol. 4:314. doi: 10.3389/fmicb. 2013.00314

This article was submitted to Terrestrial Microbiology, a section of the journal Frontiers in Microbiology.

Copyright (c) 2013 Dhami, Reddy and Mukherjee. This is an open-access article distributed under the terms of the Creative Commons Attribution License (CC BY). The use, distribution or reproduction in other forums is permitted, provided the original author(s) or licensor are credited and that the original publication in this journal is cited, in accordance with accepted academic practice. No use, distribution or reproduction is permitted which does not comply with these terms. 